to the private sphere: from intimacy, to sex, to care of the body, to sports and leisure, dancing and fashion. They highlight the tensions and contradictions between old and new practices and the ways new forms of mass consumption also helped define new roles for individuals within the family and society at large. The chapters contained in Part II relate to particular cultural industries as they struggled between political and cultural constraints and the needs and shapes of the Italian market. These chapters are particularly concerned with the monopoly and power that American cultural giants, such as Walt Disney or MGM, had in Italy, and they highlight the continued presence of American cultural products in the Italian market well into the Fascist period. Finally, Part III considers the impact of state intervention on mass culture, as well as the efforts of particular collectivities to influence mass culture and its consumption. The Fascist Party, the Catholic Church and the Communist Party all had to reconcile a desire to intervene in the moral and ethical shape of mass cultural products with the need to attract and please mass audiences. None of these collectivities, however powerful, were ever able to achieve full ideological conversion via the sphere of leisure. Not only that, but leisure often indirectly assisted in the spread of consumption and radically altered the shape of the very society these groups were hoping to influence.

This volume certainly helps fill a gap in the understanding of the continuities and particularities of Italian mass culture from the late 1930s to the 1950s. The variety of the sources presented, as well as the broad treatment of mass culture - made to include aspects such as the cult of stars and neglected facets of the publishing industry, such as children's comics and the fotoromanzo-make this a useful source for understanding that era of Italian history, as well as the development of contemporary mass culture more broadly. There is a sense, perhaps, that the extensive oral history sources collected-including over 200 hours of recordings and 4000 pages of transcripts - could have been put to broader use and that fascinating details of personal relations with stars, with radio and with the cinema are still waiting to be uncovered where they are stored in the Economic and Social Data Service (ESDS) Qualidata at the University of Essex.

Such criticism aside, this is a timely and valuable contribution to our understanding of mass culture in Italy which presents complex and sometimes highly culturally specific details in a style that makes the book accessible and relevant to readers well beyond Italian studies.

Eleanor Chiari

University College London, UK ucljec0@ucl.ac.uk (C) 2009, E. Chiari

\title{
Europe in the Global Age
}

Anthony GIDDENS

Polity, 2007, ISBN 978-0-7456-4012-9

$£ 12.99$ (pbk), 246 pp.

The European Union (EU) and its member states face major challenges, triggered by globalisation, changes in the lifestyles of its citizens, the recent enlargement rounds and 
economic downturns. Although most of these challenges are similar for all industrialised countries, the related problems and issues need to be viewed in a different light for Europe. Giddens considers the European Social Model (ESM) as the jewel in the crown of European societies. With this claim in mind the book Europe in the Global Age starts its journey across issues and problems that put the ESM under strain and formulates policy solutions to release some of the pressure.

In the opening chapter the main components of the European Social Model are identified, consisting of an interventionist state, a robust welfare system aimed at those most in need and the limitation of economic and other forms of inequality. Although this model is in general under strain, Giddens shows that some European countries have been able to uphold it. By listing the best practices around Europe, it is pointed out that bad performers can learn from best practices in other European countries. The Scandinavian countries especially have been able to structure their societies in such a way as to ensure a high employment rate of men and women, combined with economic dynamism and environmental protection. However, there is a need to go beyond best practice and set even more ambitious targets to deal with, for example, the integration of migrants, the enlargement of the EU and the shift from 'positive' to 'negative' welfare.

The chapters that follow are structured along the lines of best practice identified in the first chapter and some additions proposed to the Lisbon agenda of 2000 — a strategy aimed at turning the EU into the most economically competitive, dynamic and socially cohesive society in the world by 2010. Before these issues are discussed, Giddens reviews in chapter 2 the worst practice of the three big underperforming EU economies (Germany, France and Italy), which he labels 'blocked societies'.

In order to compare the performance and policies of European countries with respect to their social cohesion, Giddens introduces, in chapter 3, a concept which is lacking in the Lisbon strategy, i.e. social justice. On the basis of an analysis of changing patterns of class, inequality and social division in European societies, Giddens proposes policies to ensure that economic equality will not be sacrificed for good growth rates. Chapter 4 deals with social issues and a new concept is introduced (i.e. positive welfare) to indicate that it is necessary to change the traditional welfare system - which sought to transfer risk from the individual to the state-into a system in which welfare is defined in terms of personal autonomy and self-esteem.

Towards the end of the book Giddens turns his attention to the EU level and explicates several improvements to the Lisbon agenda, such as increasing the attention to environmental problems, broadening the social agenda and assigning a greater role to universities in the knowledge/service society. The last two parts of the book (one chapter and one open letter) take the form of political pamphlets in which Giddens-among other things - specifies eight theses on the future of Europe, ranging from the underestimated effects of 1989 and the fall of the Berlin Wall to the 'why' of European integration.

The main asset of the book is the discussion of a wide range of issues prominent in current debates about socio-economic developments in Europe. It touches upon some of the main challenges that the EU and its member states need to address in the near future and offers solutions that are detailed enough from which to derive concrete policies. The direction for solutions Giddens hints at will have a greater appeal to centre-left politicians, because of the emphasis on the Lisbon strategy-which has been presented from the outset as a Third Way agenda for the EU (Agence Europe, 2000)—linked to the political programme of former UK prime minister Tony Blair and a stress on the need for 
a balancing act between economic competitiveness and social justice. Next to its political relevance, undergraduate students may find it a useful book to link academic debates with ongoing political discussions.

However, as a result of the variety of issues discussed-e.g. from obesity to migration and from poverty to free speech - the chapters provide only a superficial overview of wellknown issues and problems. Moreover, several concepts are underspecified, for example, given that the ESM is central to the book, more information should have been provided on which academic contributions Giddens based his definition. To be fair, the book is not purely aimed at a scholarly public and does not need to make a link with the literature explicit to let the reader understand the general message of the book: social justice and economic competitiveness can and should go hand in hand in the twenty-first century.

\title{
Reference
}

Agence Europe (2000) Joint statement by the United Kingdom and Belgium calls for summit to add initiatives for social inclusion to the Luxembourg process and to adopt an SME chapter. Available online at http://www.agenceurope.com.

\author{
Rik de Ruiter \\ University of Twente, The Netherlands \\ r.deruiter@utwente.nl \\ (C) 2009, R. de Ruiter
}

\author{
Global Europe Social Europe \\ Anthony GIDDENS, Patrick DIAMOND and Roger LIDDLE (Eds) \\ Polity, 2007, ISBN 978-07456-3935-2 \\ $£ 16.99$ (pbk), 309 pp.
}

'The active welfare state must be a trampoline for success, not a safety net that cushions people from failure for the rest of their lives' argues Diamond with regard to the new frontiers of the European welfare state. It must extend personal freedom, harness individual potential and guarantee social justice. Clearly a global, social Europe goes beyond social policy. It implies a complex discussion of developments and linkages between issues of trade, enlargement, environment (Gothenburg), research and development and knowledge transfer (Lisbon), gender equality, ageing, healthcare, migration, taxation and social justice, as well as-there's no escaping it-globalization.

The 15 forward looking chapters by researchers and practitioners from politics, business, public affairs, think-tanks and academia advocate desirable future scenarios, based on a difficult mix of policy analysis and political instinct. They contain subtitled sections such as 'lessons to be learned', 'a template for reform' and 'implications for policy'. Thus, the discussions are academically informed rather than academic in an analytical sense, with anecdotal statistics, hefty percentages and hyperbolic comparisons meant to convince, prod and prompt decision-makers into action.

The editors all have an academic connection with the London School of Economics and a political link to the UK's New Labour government, either in an advisory or 